\title{
Intramammary Infusion of Leptin Decreases Proliferation of Mammary Epithelial Cells in Prepubertal Heifers
}

\author{
L. F. P. Silva, ${ }^{\star}$ B. E. Etchebarne, $†$ M. S. Weber Nielsen, $†$ J. S. Liesman, $†$ M. Kiupel, $\ddagger$ and M. J. VandeHaar ${ }^{1}$ \\ *Department of Animal Nutrition and Production, University of São Paulo, Pirassununga, Brazil, 13635-900 \\ †Department of Animal Science, and \\ ‡Department of Pathobiology and Diagnostic Investigation, Michigan State University, East Lansing 48824-1225
}

\section{ABSTRACT}

High energy intake and excessive body fatness impair mammogenesis in prepubertal ruminants. High energy intake and excessive fatness also increase serum leptin. Our objective was to determine if an infusion of leptin decreases proliferation of mammary epithelial cells of prepubertal heifers in vivo. Ovine leptin at $100 \mu \mathrm{g} /$ quarter per $\mathrm{d}$ with or without $10 \mu \mathrm{g}$ of insulin-like growth factor (IGF)-I was infused via the teat canal into mammary glands of prepubertal dairy heifers; contralateral quarters were used as controls. After $7 \mathrm{~d}$ of treatment, bromodeoxyuridine was infused intravenously and heifers were slaughtered $\sim 2 \mathrm{~h}$ later. Tissue from 3 regions of the mammary parenchyma was collected and immunostained for bromodeoxyuridine (BrdU), proliferating cell nuclear antigen (Ki-67), and caspase-3. Leptin decreased the number of mammary epithelial cells in the S-phase of the cell cycle by $48 \%$ in IGF-I-treated quarters and by $19 \%$ in saline-treated quarters. Leptin did not alter the number of mammary epithelial cells within the cell cycle, as indicated by Ki-67 labeling. Caspase-3 immunostaining within the mammary parenchyma was very low in these heifers, but leptin significantly increased labeling in salinetreated quarters. Leptin enhanced SOCS-3 expression in IGF-I-treated quarters but did not alter SOCS-1 or SOCS-5 expression. We conclude that a high concentration of leptin in the bovine mammary gland reduces proliferation of mammary epithelial cells. The reduced proliferation is accompanied by an increase in SOCS-3 expression, suggesting a possible mechanism for leptin inhibition of IGF-I action. Whether leptin might be a physiological regulator of mammogenesis remains to be determined.

Key words: mammary gland, leptin, insulin-like growth factor-I, proliferation

Received October 8, 2007.

Accepted March 27, 2008.

${ }^{1}$ Corresponding author: mikevh@msu.edu

\section{INTRODUCTION}

Mammary development is controlled by a complex interplay of circulating hormones and locally acting factors (Cowie et al., 1980; Akers et al., 2000). In prepubertal, postweaned heifers, high energy diets impair the development of mammary parenchyma (Sejrsen and Purup, 1997). Part of this impairment can be explained by accelerated puberty, but other factors likely also are involved.

We suggest that leptin may be involved in the nutritional impairment of bovine mammogenesis. High energy diets increase leptin concentrations in serum and mammary tissue and abundance of leptin mRNA in mammary tissue (Blache et al., 2000; Davis-Rincker, 2005; Thorn et al., 2006). In addition, the long form of the leptin receptor $(\mathrm{Ob}-\mathrm{Rb})$ is expressed by bovine mammary epithelial cells, albeit at low levels (Silva et al., 2002a; Chelikani et al., 2003; Thorn et al., 2006), providing a means for leptin to influence mammary epithelial cells. Exogenous bovine and ovine leptin inhibited proliferation of bovine mammary epithelial cells in vitro (MAC-T cell line) in one study (Silva et al., 2002a), but not in another (Thorn et al., 2006). In another study, bovine leptin inhibited the formation of duct-like organoids in bovine mammary epithelial cells in collagen gel 3-dimensional culture in vitro (Yamaji et al., 2007).

Increased concentrations of leptin $(\sim 100 \mathrm{n} M)$ had differing effects on epithelial cell proliferation of numerous human and mouse mammary epithelial cell culture lines. Although some investigators have reported increased proliferation in cancerous cell lines (Hu et al., 2002), others reported that physiologically normal cell lines do not exhibit increased proliferation in response to the hormone or even a decrease in proliferation $(\mathrm{Hu}$ et al., 2002; Baratta et al., 2003). Because obesity increases circulating leptin concentrations, the mitogenic action of leptin in physiologically normal human mammary epithelial cells or breast cancer cells is consistent with the link between postpubertal obesity and breast cancer in humans (Hutt and DeWille, 2002). However, 
multiple studies have shown that high energy diets and obesity impair mammary development in prepubertal ruminants (Sejrsen and Purup, 1997; Silva et al., 2002b). Thus, studies on the effects of leptin in human or rodent mammary tissues may not be relevant for prepubertal heifers. Furthermore, studies with isolated epithelial cells may not be relevant for the intact gland. To our knowledge, no studies have been reported effects of exogenous leptin on mammary epithelial cells in the intact mammary gland. We hypothesized that increased leptin concentrations inhibit proliferation of mammary epithelial cells in prepubertal heifers in vivo. We tested this hypothesis using a physiologically normal bovine mammary model in which the various mammary cell types and the normal milieu of physiological regulators was present.

The objective of our study was to determine if intramammary infusion of leptin in prepubertal heifers would decrease proliferation of mammary epithelial cells in vivo in the presence or absence of exogenous IGF-I. A second objective was to identify possible mechanisms by which leptin might inhibit IGF-I action. Because no studies have examined exogenous leptin infusions by the intramammary route, we used a high dose of leptin in this study to determine if leptin had a biological effect on mammary cell proliferation, regardless of whether the effect was physiological or supraphysiological.

\section{MATERIALS AND METHODS}

\section{Animals}

Six prepubertal Holstein heifers (Bos taurus) weighing $209 \pm 10 \mathrm{~kg}$ were purchased and housed in individual stalls at the Beef Cattle Research Center of Michigan State University. Heifers were fed once a day a corn silage-based diet at restricted intake formulated to achieve a body weight gain of $700 \mathrm{~g} / \mathrm{d}$, according to standard recommendations (NRC, 2001). This growth rate was selected to promote normal mammary development (Sejrsen and Purup, 1997). Heifers had free access to water. Experimental procedures were approved by the Michigan State University Animal Use and Care Committee.

\section{Infusion Procedure}

Heifers were adapted to diet and environment for 10 $d$ before the start of infusions. The front or rear halves of the udder were treated as separate blocks and randomly assigned to receive intramammary infusions of IGF-I or saline. To balance for the effects of block, 2 heifers were infused at each time, one with IGF-I infusions in the front half, and the other with IGF-I infusions in the rear half. The left and right side of each block were assigned randomly to receive intramammary infusions of recombinant ovine leptin (oLeptin) or saline over a 7-d infusion period. Treatments were then defined as IGF-I (IGF), IGF-I + oLeptin (IGF+LEP), saline (SAL), and saline + oLeptin (SAL+LEP). Thus, each treatment was applied to a total of 6 quarters, one in each heifer, and the effect of oLeptin always was compared against its contralateral quarter.

Lyophilized recombinant human IGF-I (GroPep Pty Ltd., North Adelaide, Australia), which is identical to bovine IGF-I, was dissolved in $10 \mathrm{mM} \mathrm{HCl}$, neutralized, and diluted in sterile, physiological saline at a concentration of $1 \mu \mathrm{g}$ of IGF-I/mL. The saline contained 1 $\mathrm{mg}$ of bovine serum albumin/mL (Invitrogen, Carlsbad, CA). Ten micrograms of IGF-I were infused daily per quarter using a 12-mL syringe with an intramammary infusion cannula. This dose of IGF-I increased mammary epithelial cell proliferation 50\% in a previous study (Silva et al., 2005).

Leptin-treated quarters were infused daily with 100 $\mu \mathrm{g}$ of oLeptin. Because the goal of this study was to determine whether leptin had any biological effect in mammary tissue, we purposely chose this high dose, recognizing that it might be supra-physiological. The concentration of leptin in mammary extracts of prepubertal heifers averages around $11 \mathrm{ng}$ of leptin/g of tissue (Silva et al., 2002a). The average mass of mammary parenchyma in the gland of a $200-\mathrm{kg}$ heifer reared on a regular energy diet is about $140 \mathrm{~g}$ (Meyer et al., 2006); therefore, there is a total of about $1.5 \mu \mathrm{g}$ of leptin in the mammary parenchyma. The half-life of leptin in human serum is reported to be about $25 \mathrm{~min}$ (Klein et al., 1996). If we assume the same half-life for leptin in the parenchymal interstitial fluid of prepubertal heifers, there would be a turnover of $43.2 \mu \mathrm{g}$ of leptin per mammary gland per day. We infused $100 \mu \mathrm{g}$ of leptin per mammary gland per day. If all of this leptin migrated out of the ducts and into the surrounding tissue intact and biologically active, our dose likely increased by 3.3-fold the amount of leptin entering the interstitial fluid of each quarter per day.

Recombinant ovine leptin was purchased from Arieh Gertler of the Hebrew University, Jerusalem, Israel, and was produced as described in Gertler et al. (1998). Lyophilized oLeptin was dissolved in saline at a concentration of $10 \mu \mathrm{g}$ of oLeptin/mL before infusion.

To avoid any microbial contamination, all materials used during infusion were sterile. The teats were cleaned with an iodine solution and the teat ends scrubbed with ethanol before infusion. The solutions infused were tested for the presence of endotoxins using a commercial kit with sensitivity to detect $0.006 \mathrm{ng}$ of endotoxin/mL (LAL, BioWhittaker, Walkersville, MD). 


\section{Sample Collection and Tissue Processing}

Heifers were slaughtered $14 \mathrm{~h}$ after last infusion. Two to three hours before slaughter, BrdU (Sigma Chemical Co., St. Louis, MO) was injected into the jugular vein at a dose of $5 \mathrm{mg}$ of BrdU/kg of BW. Heifers were killed with a sodium pentobarbital injection ( $86 \mathrm{mg} / \mathrm{kg}$ of BW). At slaughter, mammary glands were removed within 5 min of death. The dissected mammary glands were carefully examined for any visual evidence of obvious bacterial infection including abnormalities such as blood, flakes, clots, and wateriness. No occurrence of infection was noticed during the experiment. Samples from 3 regions of the mammary parenchyma (proximal, intermediate, and distal to the teat) were collected and fixed in 10\% neutral buffered formalin for $18 \mathrm{~h}$ (Sigma). At this time mammary samples ( $5 \mathrm{~g}$ each) from each of the 3 regions of the mammary parenchyma were collected for RNA extraction, sealed individually, and snap frozen in liquid nitrogen for storage at $-80^{\circ} \mathrm{C}$ until use.

\section{Microscopic Evaluation}

To determine if infusions caused any inflammatory response, formalin-fixed mammary tissues from the intermediate region of each quarter were routinely processed, paraffin-embedded, and sectioned at $6-\mu \mathrm{m}$ thickness and stained with eosin and hematoxylin. Microscopic evaluation of each tissue sample was performed without knowledge of sample identity by M. Kiupel, a board-certified veterinary pathologist. The severity of periglandular eosinophilic and lymphoplasmacytic infiltration was scored using a 1 to 6 scale with 1 being no inflammation and 6 being severe.

\section{BrdU Immunohistochemistry}

Formalin-fixed samples were dehydrated using a series of ethanol solutions (70, 90, and 100\%) for $2 \mathrm{~h}$ each, and cleared in xylene for $2 \mathrm{~h}$ before being embedded in paraffin blocks. Paraffin-embedded samples were sectioned at $6 \mu \mathrm{m}$ onto poly-L-lysine-treated slides (Sigma), deparaffinized in xylene, rehydrated in descending concentrations of ethanol, and rinsed in deionized water. Slides were incubated for $10 \mathrm{~min}$ in hydrogen peroxide $(3 \%)$ to remove intrinsic peroxidase activity and washed in deionized water. Slides were then heated in a microwave oven in citrate buffer $(10 \mathrm{mM})$ for antigen retrieval and washed in PBS. After incubation of the slides in nonimmune goat serum for $10 \mathrm{~min}$, tissue sections were incubated overnight in a humid chamber with a BrdU monoclonal antibody (clone BMC 9318, Roche, Indianapolis, IN) at a dilution of 1:50, according to procedures described by Capuco et al. (2001).
The BrdU-immunostaining was visualized with the chromogen diaminobenzidine using the Histostain-SP kit (Zymed Laboratories Inc., San Francisco, CA). Tissue sections were treated with a biotinylated goat secondary antibody against mouse immunoglobulin. They were then incubated with streptavidin horseradish peroxidase, which binds to the biotinylated secondary antibody. A solution containing diaminobenzidine was used as the horseradish peroxidase substrate to generate a brown precipitate. Slides were counterstained with hematoxylin, rinsed, dehydrated, cleaned with xylene, and mounted with Permount (Zymed). Cells containing BrdU were identified by a brown stain over the nucleus (Figure 1A). Total epithelial cells and BrdU-labeled epithelial cells were quantified in 3 microscopic fields from each slide section ( $\mathrm{n}=1$ section per quarter). Cells were enumerated by 2 independent evaluators blinded to the identity of the samples, and an average of 2,935 epithelial cells was counted in each quarter to calculate the percentage of cells labeled with BrdU.

\section{Ki-67 Immunohistochemistry}

Immunohistochemical analysis of Ki-67 labeling was performed as described previously (Kiupel et al., 1999). Room temperature paraffin-embedded tissue samples were incubated in $10 \mathrm{mM} \mathrm{HCl} /$ citrate buffer ( $\mathrm{pH}$ 6.0) and heated in a microwave oven $(600 \mathrm{~W})$ for $25 \mathrm{~min}$. Slides were transferred to $100 \%$ ethanol and immersed in methanol containing $1 \%$ hydrogen peroxide for 30 min to block endogenous peroxidase activity. Sections were then washed in distilled water and PBS $(\mathrm{pH} 7.6)$ containing normal equine serum for 15 min to block nonspecific antibody binding. A mouse anti-Ki-67 antibody was used for immunostaining (Immunotech S.A., Marseille, France) at a dilution of 1:200 in 10\% normal equine serum for $60 \mathrm{~min}$. Antibody binding was visualized with the Vector ABC Elite kit (Vector Laboratories) with 3,3'-diaminobenzidine substrate (Vector Laboratories). Final washing was performed in distilled, deionized water. Sections were then counterstained with Mayer's hematoxylin, then dehydrated, cleared, and mounted in DPX (BDH). Equine lymphoid tissue was used as a positive control (Kiupel et al., 1999). Total epithelial cells and Ki-67-labeled epithelial cells were quantified in 3 microscopic fields from each of 3 slide sections (Figure 1B). Two independent evaluators blinded to the identity of the samples determined the percentage of Ki-67 labeling, counting an average of 1,710 epithelial cells per quarter.

\section{Caspase-3 Immunohistochemistry}

Cell death analysis was performed as described by Kiupel et al. (2005). Tissue sections were deparaffinized 


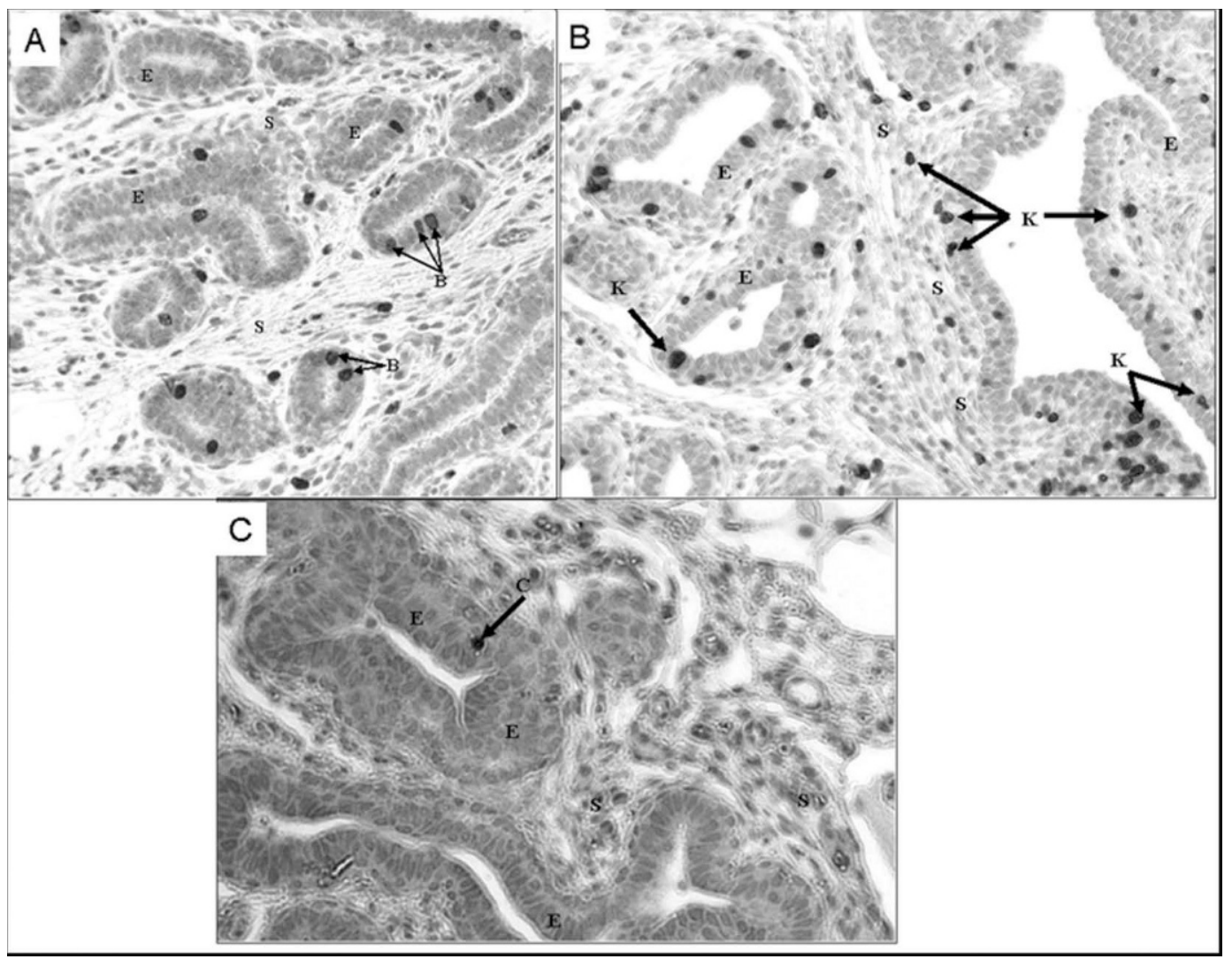

Figure 1. Representative mammary parenchymal sections immunostained for A) bromodeoxyuridine (BrdU), B) proliferating cell nuclear antigen (Ki-67) and C) caspase-3. B = BrdU-positive cells (darker), $\mathrm{K}=\mathrm{Ki}$-67-positive cells (darker), $\mathrm{C}=$ caspase-3-positive cells (darker), $\mathrm{E}=$ epithelial cells, and $\mathrm{S}=$ stromal cells .

and incubated in target retrieval solution (Dako Corporation, Santa Barbara, CA) for 15 min at 95 to $99^{\circ} \mathrm{C}$. Immunostaining was performed using the Dako Autostainer (Dako) by incubation with a polyclonal antimouse anti-activated caspase- 3 antibody (R\&D Systems, Minneapolis, MN) at a dilution of $1: 100$ at $-4^{\circ} \mathrm{C}$ overnight, followed by a 1:500 dilution of a biotinylated goat anti-rabbit secondary antibody (Dako). A peroxidase-labeled streptavidin-biotin complex (Dako) was used for antibody binding localization, after which antibody binding was visualized with a $3,3^{\prime}$-diaminobenzidine as a chromogen substrate. After a final wash in automation buffer, sections were counterstained with Lerner's hematoxylin. Sections incubated with isotype control antibodies were used as negative controls (Kiupel et al., 2005). Total epithelial cells and caspase-3labeled epithelial cells were quantified in 3 microscopic fields from each of 3 slide sections (Figure 1C). Two independent evaluators blinded to the identity of the samples determined the percentage of caspase-3 label- ing, with an average of 3,136 epithelial cells counted per quarter.

\section{Analysis of Leptin in Mammary Parenchymal Extracts}

Approximately $1 \mathrm{~g}$ of parenchymal tissue collected from the region intermediate to the teat was homogenized for 1 min using an electronic homogenizer (Polytron, Lucerne, Switzerland) with $3 \mathrm{~mL}$ of saline in 15mL Corex tubes (Fisher Scientific, Pittsburgh, PA). The tubes were kept on ice. Twenty-five microliters of a protease inhibitor cocktail (Sigma) was added to the homogenates, and the homogenates were shaken at $4^{\circ} \mathrm{C}$ for $90 \mathrm{~min}$. Homogenates were centrifuged (Sorvall Instruments, Newton, CT) at $10,000 \times g$ at $4^{\circ} \mathrm{C}$ for 45 min. Supernatants were transferred to new $15-\mathrm{mL}$ Corex tubes and centrifuged again at $10,000 \times g$. Supernatants were recovered and stored at $-20^{\circ} \mathrm{C}$. Leptin concentrations in serum and mammary extracts were 
determined by D. Keisler (University of Missouri) using a double-antibody radioimmunoassay (Delavaud et al., 2000).

\section{RNA Isolation Procedure}

Approximately $200 \mathrm{mg}$ of frozen mammary tissue from the intermediate parenchymal region was weighed and directly added to $3 \mathrm{~mL}$ of Trizol reagent in a 15-mL culture tube. Tissue was homogenized using a Polytron for $\sim 30 \mathrm{~s}$. Between homogenization of individual samples, the Polytron probe was rinsed with diethyl pyrocarbonate (DEPC, Sigma)-treated water, and RNase Away (Molecular BioProducts, San Diego, CA). Samples were aliquotted into three $1.5-\mathrm{mL}$ centrifuge tubes, and total RNA was extracted essentially as recommended by the manufacturer (Invitrogen). Isolated RNA was then subjected to DNase treatment (RQ1 RNase-free DNase, Promega, Madison, WI) following the manufacturer's protocol (Promega).

A phenol/chloroform separation step was performed by adding RNase-free water $(37 \mu \mathrm{L})$ and phenol/chloroform $(100 \mu \mathrm{L})$. The tube was shaken and centrifuged for $2 \mathrm{~min}$ at $14,000 \times g$. The upper phase $(-90 \mu \mathrm{L})$ was transferred to a fresh tube, sodium acetate $(3 M, 9 \mu \mathrm{L})$ and ethanol $(250 \mu \mathrm{L})$ were added to this phase, and the mixture was stored overnight at $-20^{\circ} \mathrm{C}$. The following day, microcentrifuge tubes were centrifuged at 14,000 $\times g$ at $4^{\circ} \mathrm{C}$ for $20 \mathrm{~min}$. The liquid was decanted and the pellet was washed with ethanol $(75 \%, 500 \mu \mathrm{L})$. The tube was centrifuged at $14,000 \times g$ at $4^{\circ} \mathrm{C}$ for $10 \mathrm{~min}$. The ethanol was decanted and the pellet was dried under air for $15 \mathrm{~min}$. The pellet was resuspended in $50 \mu \mathrm{L}$ of nuclease-free water and incubated at $60^{\circ} \mathrm{C}$ for $10 \mathrm{~min}$. The quantity of RNA was determined using the NanoDrop ND-1000 Spectrophotometer (NanoDrop Technologies, Wilmington, DE), and quality was checked with a RNA 6000 Nano LabChip kit and Agilent 2100 BioAnalyzer (Agilent Technologies, Palo Alto, CA).

\section{Quantitative RT-PCR}

The expression of leptin response genes SOCS-1, SOCS-3, and SOCS-5 was measured using quantitative real-time reverse transcription-PCR (Q-RT-PCR) with an Applied Biosystems 7000 DNA Sequence detection system (Perkin Elmer Corp., Foster City, CA). The RNA was converted into first-strand cDNA by adding $1 \mu \mathrm{g}$ of total RNA to a $12-\mu \mathrm{L}$ reaction containing $10 \mathrm{mM}$ oligo $(\mathrm{dT})_{18}$ primer. Following a 5-min incubation at $70^{\circ} \mathrm{C}$, the reaction was chilled on ice and $\mathrm{pH}$ adjusted by addition of $4 \mu \mathrm{L}$ of a buffer supplied by the reverse transcriptase manufacturer (final reagent concentrations were $50 \mathrm{~m} M$ Tris- $\mathrm{HCl}, \mathrm{pH} 8.3,75 \mathrm{~m} M \mathrm{KCl}$, and
$3 \mathrm{~m} M \mathrm{MgCl}_{2}$ ), $1 \mathrm{~m} M$ deoxynucleoside triphosphates, and 200 units of Superscript II RNase H reverse transcriptase (Invitrogen). Incubation at $37^{\circ} \mathrm{C}$ continued for $30 \mathrm{~min}$ in the presence of RNase-H to remove the original RNA templates. Heating at $70^{\circ} \mathrm{C}$ for 15 min subsequently inactivated RNase-H. The reaction tubes were removed from the thermocycler, and $0.2 \mu \mathrm{L}$ of $0.5 \mathrm{M}$ EDTA was added and mixed. Then, $25 \mu \mathrm{L}$ of water, 5 $\mu \mathrm{L}$ of $3 \mathrm{M}$ sodium acetate, and $125 \mu \mathrm{L}$ of ethanol $\left(-20^{\circ} \mathrm{C}\right)$ were added to the tube. Tubes were then allowed to precipitate overnight at $-20^{\circ} \mathrm{C}$.

The reaction mixture containing the newly synthesized cDNA was transferred to a new, clean microcentrifuge tube. These tubes were then centrifuged at 14,000 $\times g$ and $4^{\circ} \mathrm{C}$ for $20 \mathrm{~min}$ and the supernatant was decanted. Pellets were washed with $250 \mu \mathrm{L}$ of ethanol $\left(75 \%,-20^{\circ} \mathrm{C}\right)$ and the tube was centrifuged at $14,000 \times$ $g$ and $4^{\circ} \mathrm{C}$ for $6 \mathrm{~min}$. The supernatant was decanted and the pellet was allowed to dry for $15 \mathrm{~min}$. The pellet was resuspended in $50 \mu \mathrm{L}$ of water and incubated at $60^{\circ} \mathrm{C}$ for $5 \mathrm{~min}$. The cDNA concentration was analyzed using a spectrophotometer (NanoDrop), and was then diluted to a final concentration of $10 \mathrm{ng} / \mu \mathrm{L}$ and stored at $-80^{\circ} \mathrm{C}$ until the Q-RT-PCR reaction was initiated.

The SYBR Green PCR Master Mix (Perkin Elmer Corp.) and gene-specific primers were used to perform Q-RT-PCR reactions. Primer Express Software (Perkin Elmer Corp.) was used to design all primers, which were then synthesized by a commercial facility (Invitrogen). Primer sequences for genes analyzed in this report are included in Table 1.

The amount of primer used was determined by performing an optimization matrix for each primer using 3 concentrations of primers: 50:50 $\mathrm{n} M, 300: 300 \mathrm{n} M$, 900:900 $\mathrm{n} M$. Dissociation curves were similar for all concentrations and the 300:300 $\mathrm{n} M$ matrix was chosen; thus, $3 \mu \mathrm{L}$ of primer was used for all experiments. Each gene of interest and the control gene were measured in duplicate. Within each well of a 96 -well reaction plate (MicroAmp Optical, Applied Biosystems), $30 \mathrm{ng}$ of sample cDNA $(3 \mu \mathrm{L}), 6.5 \mu \mathrm{L}$ of DEPC water, $3 \mu \mathrm{L}$ of primer, and 12.5 $\mu \mathrm{L}$ of Sybr Green PCR Master Mix (Applied Biosystems) were added.

The $2^{-\Delta \Delta \mathrm{CT}}$ method of Q-RT-PCR analysis was performed as described previously (Livak and Schmittgen, 2001). In this study analysis GAPDH was used as the control gene to calculate initial $\Delta \mathrm{C}_{\mathrm{T}}$ values because it has previously been shown to be an appropriate control gene in experiments with mammary tissue (Smith and Sheffield, 2002). This method allows for the determination of relative gene expression changes across treatments based on quantitative differences in the PCRamplified target reaching a fixed threshold cycle $\left(\mathbf{C}_{\mathbf{T}}\right)$ number for a specific treatment versus other treat- 
Table 1. Oligonucleotide primer pairs designed for PCR amplification

\begin{tabular}{|c|c|c|}
\hline Gene & Primer sequence $\left(5^{\prime} \rightarrow 3^{\prime}\right)$ & GenBank accession \\
\hline GAPDH & $\begin{array}{l}\text { Forward: GCATCGTGGAGGGACTTATGA } \\
\text { Reverse: GGGCCATCCACAGTCTTCTG }\end{array}$ & NM_001034034 \\
\hline SOCS-1 & $\begin{array}{l}\text { Forward: CCCACATGGTCCAGGAAAAT } \\
\text { Reverse: GCTCCTTCCCCTTCCAGATC }\end{array}$ & XM_864316 \\
\hline SOCS-3 & $\begin{array}{l}\text { Forward: GAGAACTGCCGGGAATCTTTG } \\
\text { Reverse: GAGGTTTAAAGCTCTGTTTTAAACCAA }\end{array}$ & NM_174466 \\
\hline SOCS-5 & $\begin{array}{l}\text { Forward: GCCCGAATTGAACAGTGGAA } \\
\text { Reverse: TTACAGTGGAGGAGTGAAACACACA }\end{array}$ & NM_001046182 \\
\hline
\end{tabular}

ments. In our $2^{-\Delta \Delta \mathrm{CT}}$ analysis, the $\mathrm{C}_{\mathrm{T}}$ for SAL was the calibrator used to determine relative expression changes for IGF, LEP, and IGF+LEP treated quarters for each GAPDH-normalized test gene.

\section{Statistical Analysis}

The data were analyzed as a strip-plot design by least squares ANOVA, where the front or rear half of the udder were the strips, and left or right glands within a strip were the plots, using the following model: $\mathrm{Y}=$ $\mu+\mathrm{IGF}+$ Leptin + IGF $\times$ Leptin + region + region $(\mathrm{IGF})$ $+\operatorname{region}($ Leptin $)+$ region $($ IGF $\times$ Leptin $)+$ heifer + $\mathrm{IGF}$ (heifer) + Leptin(heifer) + region(heifer) + IGF $\times$ Leptin(heifer) + e, where IGF is saline or IGF-I infusion, leptin is saline or leptin infusion, and region is the parenchymal regions sampled (proximal, intermediate, and distal to the teat).

The MIXED procedure of SAS (SAS Institute Inc., 2000) was utilized with the data log-transformed to remove heterogeneity of variance. Treatment means were compared by contrast, and the data are presented as back-transformed. Estimates of variance were calculated as confidence intervals from the transformed data. The BrdU- and Ki-67-labeling among parenchymal regions was compared by Bonferroni $t$-test adjusted for 3 comparisons (Neter et al., 1996).

The effect of IGF-I was tested with IGF-I(heifer), and leptin was tested with IGF $\times$ Leptin(heifer) as the error term. Gene-specific standard errors were estimated using independent ANOVA, which included the effects of quarter and treatment. All statistical analyses were performed using the SAS system (SAS Institute Inc., 2000).

\section{RESULTS}

\section{Microscopic Examination}

The infused solutions did not contain any detectable endotoxin, and no indication of infection or inflammation was observed upon gross dissection. Histopathology of the intermediate sections of each quarter indi- cated a possible hypersensitivity reaction of some tissues to the mammary infusates. However, treatment had no impact on the degree of inflammation. Pathology scores were 4.3, 3.0, 2.7, and 3.7 for the saline, leptin, IGF, and IGF+Lep treatments, respectively, with an average SEM of 0.8. There was no correlation of the pathology score to BrdU-incorporation across all quarters $(r=0.01)$ or across animals $(r=0.06)$. Moreover, an examination of glands from 4 age-matched, noninfused heifers revealed similar infiltration of eosinophils, with scores ranging from 1 to 4 and averaging 2.0. Thus, these data demonstrate that an inflammatory response was not involved in the leptin response.

\section{Immunohistochemistry}

Intramammary infusion of leptin decreased BrdUlabeling of mammary epithelial cells (Figure 2A). In both saline- and IGF-I-treated quarters, infusion of Leptin decreased the percentage of cells in the S-phase of the cell cycle. Leptin decreased $(P<0.001)$ BrdUlabeling by $48 \%$ in IGF-I-treated quarters (4.1 vs. $7.9 \%)$ and decreased $(P=0.04)$ BrdU-labeling only $19 \%$ (5.0 vs. $6.2 \%$ ) in saline-treated quarters (Figure 2A).

There was no difference $(P=0.9)$ in BrdU-labeling among the 3 parenchymal regions in saline-treated quarters (Figure 2B). The same was true for quarters receiving IGF and SAL+LEP infusions. For quarters infused with IGF+LEP, BrdU-labeling in the parenchymal region distal to the teat was higher $(P=0.03)$ than in the intermediate region (6.0 vs. $3.0 \%$, Figure $2 \mathrm{~B}$ ). This indicates that the response to oLeptin in IGF-Itreated quarters was different among the parenchymal regions $(P=0.02)$.

Concentration of leptin in mammary extracts of SAL and IGF quarters was $1.6 \pm 0.2 \mathrm{ng} / \mathrm{mL}(6.4 \pm 0.8 \mathrm{ng} / \mathrm{g}$ tissue) and increased to $43 \pm 9 \mathrm{ng} / \mathrm{mL}(170 \pm 40 \mathrm{ng} / \mathrm{g}$ of tissue) in IGF+LEP and SAL+LEP quarters. Serum concentration of leptin was $3.8 \pm 0.1 \mathrm{ng} / \mathrm{mL}$.

\section{Cell Cycle Commitment Is Unaffected by Treatment}

The number of cells committed to the cell cycle was unaffected by hormonal infusion as measured by the 

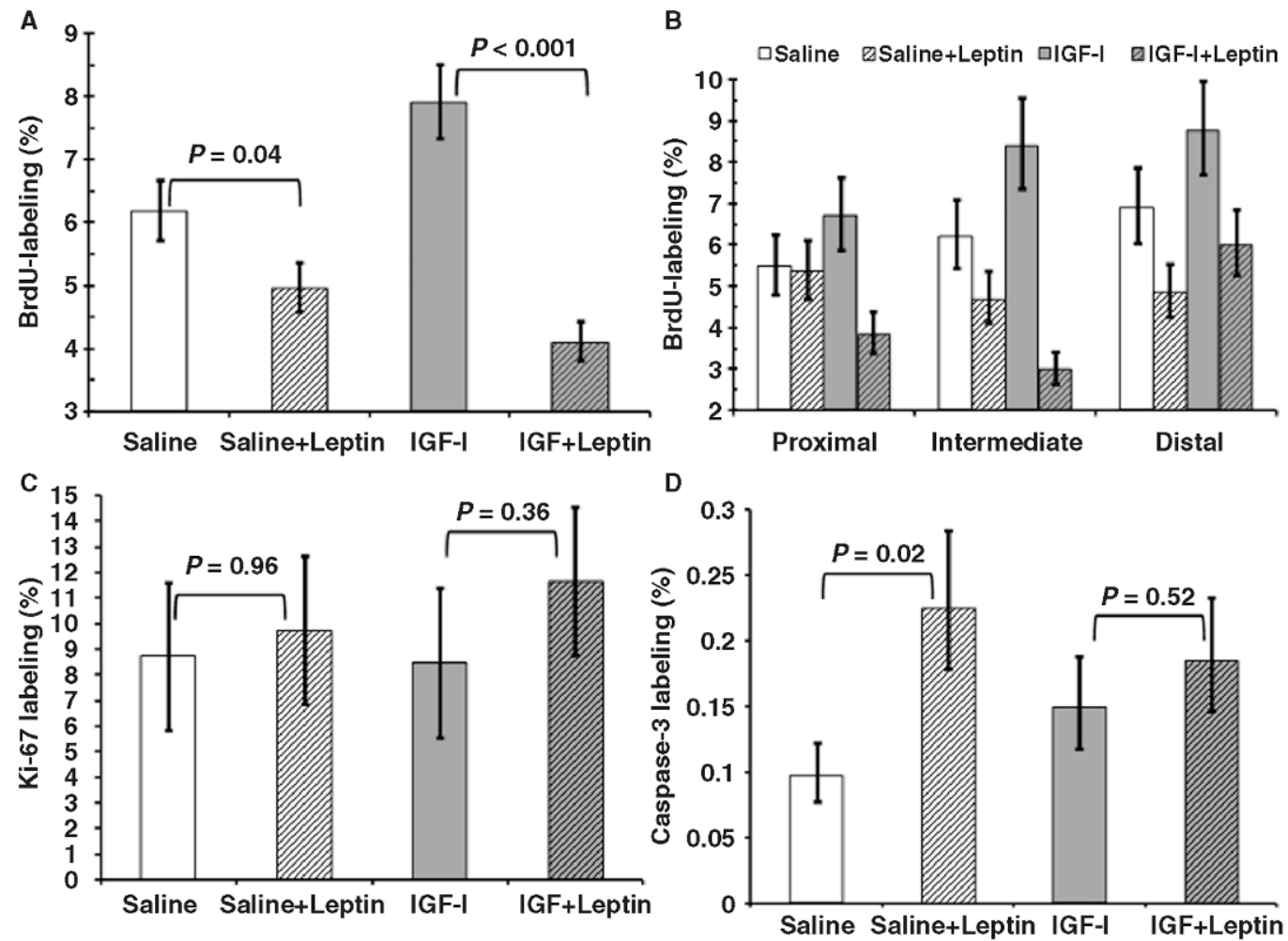

Figure 2. Effects of intramammary infusion of ovine leptin and IGF-I on the percentage of cells labeled with A) bromodeoxyuridine (BrdU) across regions, B) BrdU-labeling within each region, C) proliferating cell nuclear antigen (Ki-67), and D) caspase-3 across parenchymal regions. Results are back-transformed. $P$-values denote significance for the effect of leptin within saline or IGF-I treatment.

percentage of cells labeled by the nuclear cell proliferation antigen Ki-67. The percentage of Ki-67 positive mammary epithelial cells ranged from 8.5 to $11.7 \%$, but did not differ significantly across SAL, IGF, LEP, and IGF+LEP treatments (Figure 2C).

The percentage of proliferating cells occupying the S-phase of the cell cycle was significantly reduced by leptin. This was calculated by dividing the percentage of BrdU-labeled cells by the percentage of Ki-67-labeled cells. Both the main effect of leptin [(LEP + IGF+LEP) $-(\mathrm{SAL}+\mathrm{IGF})](P=0.015)$ and the IGF versus IGF+LEP contrast $(P=0.02)$ were highly significant.

\section{Apoptosis in Prepubertal Mammary Epithelial Cells Is Low}

Using immunohistochemical staining against activated caspase-3 as a marker of cell apoptosis (Figure $2 \mathrm{D})$, the pattern of programmed cell death in each quarter was measured. The overall percentage of apoptotic cells was very low (less than $0.25 \%$ ). Leptin significantly increased apoptosis, as marked by caspase-3 immunostaining, in saline-treated quarters, but not in IGF-Itreated quarters (Figure 2D).

\section{Q-RT-PCR Analysis Reveals Potential IGF-I and Leptin Signaling Pathway Interaction}

Three genes believed to be potentially involved with IGF-I and leptin signaling in the mammary gland, suppressor of cytokine signaling 1 (SOCS-1), SOCS-3, and SOCS-5, were measured by Q-RT-PCR. No significant differences in any treatment contrasts were detected for expression of SOCS-1 or SOCS-5 (Figure 3A and 3B). Leptin infusion increased SOCS-3 mRNA expression 3.4-fold in IGF-treated quarters (Figure 3C, $P<$ $0.05)$.

\section{DISCUSSION}

Our data show for the first time that a large increase in leptin concentration in the intact bovine mammary gland decreases the proliferation of epithelial cells. These findings provide a possible mechanism for the well-established link between high energy intake and impaired mammary development in prepubertal ruminants. We propose that IGF-I and leptin might play counter-regulatory roles in the nutritional regulation of prepubertal bovine mammary development. High en- 

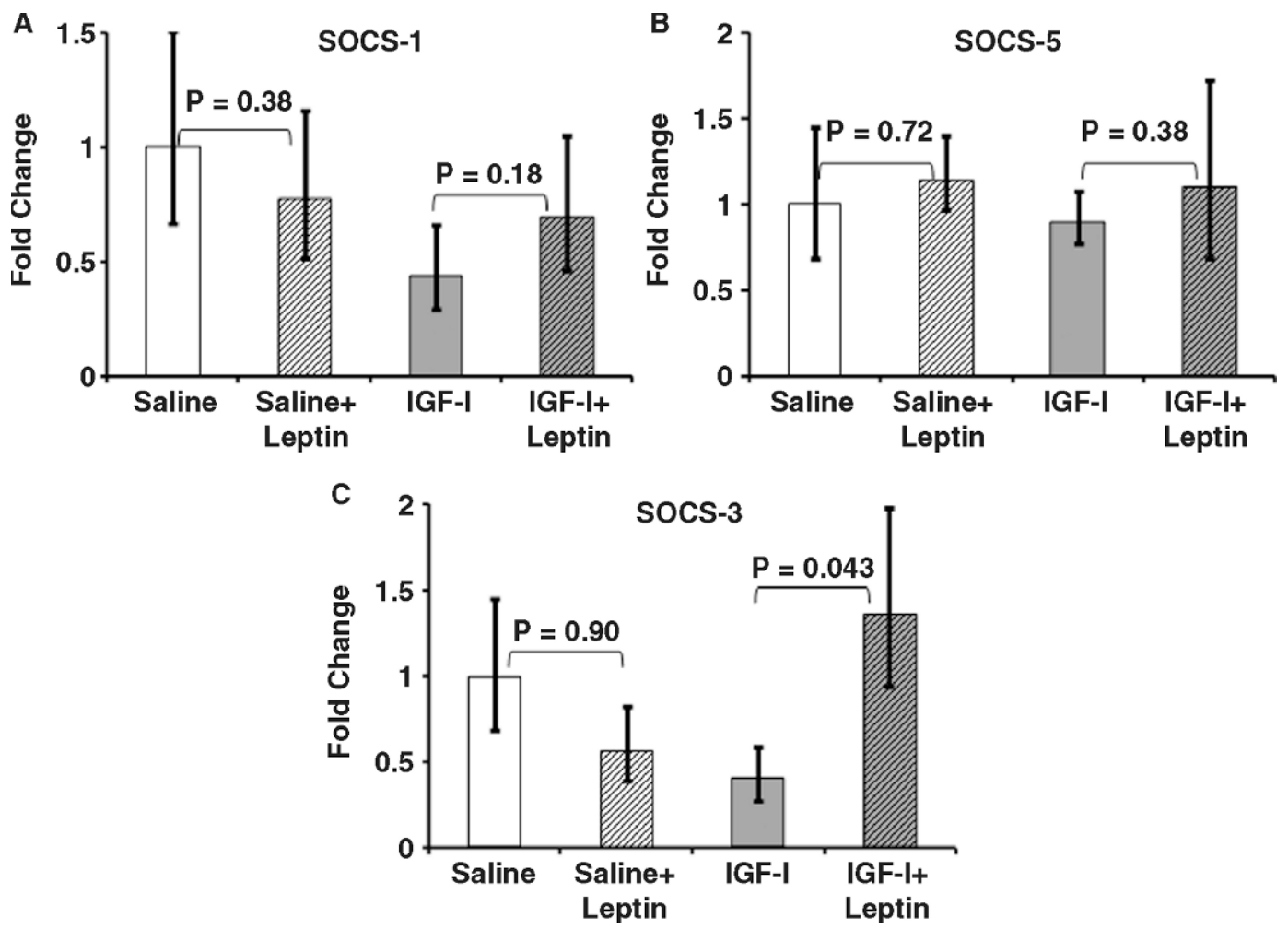

Figure 3. Effects of intramammary infusion of ovine leptin and IGF-I on the expression of mRNA coding for suppressors of cytokine signaling with A) SOCS-1, B) SOCS-3, and C) SOCS-5. Data are presented as relative expression changes for IGF-I, Leptin, and IGF+Leptin treated quarters for each GAPDH-normalized test gene in comparison with saline-treated quarters. $P$-values denote significance for the effect of leptin within saline or IGF-I treatment.

ergy diets increase both serum circulating IGF-I (Sejrsen and Purup, 1997; Radcliff et al., 2004) and leptin concentrations (Davis Rincker, 2005). However, whereas the elevated IGF-I would be expected to stimulate mammogenesis (Silva et al., 2005), as shown in the current study, the elevated leptin might negate the IGF-I-stimulation. Thus, high energy diets might decrease prepubertal mammogenesis by increasing the rate of body growth and hastening puberty without a concurrent increase in the rate of mammary growth.

Other evidence also supports this idea. Increased body fat mass in prepubertal heifers is associated with decreased mammogenesis (Silva et al., 2002b). The presence of adipose tissue in mammary organoid cultures inhibits proliferation of bovine mammary epithelial cells (McFadden and Cockrell, 1993). The long form of the leptin receptor, Ob-Rb, is expressed, albeit at low levels, in the epithelial cells of bovine mammary tissue and in intact mammary parenchyma (Silva et al., 2002a; Chelikani et al., 2003). Leptin inhibited proliferation in vitro of the MAC-T bovine mammary epithelial cell line (Silva et al., 2002a) and inhibited the formation of duct-like organoids in bovine mammary epithelial cells in collagen gel (Yamaji et al., 2007). Finally, Ob-
$\mathrm{Rb}$ has signaling capabilities similar to the interleukin6 (IL-6) receptor, and IL-6 inhibits proliferation of bovine and human mammary epithelial cells in culture (Baumann et al., 1996; Chiu et al., 1996).

In our study, leptin reduced proliferation of IGF-Itreated quarters more than in saline-treated quarters. These results agree with our in vitro experiments in which leptin decreased DNA synthesis of MAC-T cells when they were stimulated with IGF-I or fetal bovine serum (FBS), but not when the cells were grown in basal media alone (Silva et al., 2002a). The fact that leptin decreased proliferation in saline-treated quarters in vivo is likely due to inhibition of endogenous IGF-I or other mitogens present in the intact mammary gland. In culture, doses of leptin from 16 to $1,000 \mathrm{ng} /$ $\mathrm{mL}$ decreased IGF-I- or FBS-stimulated DNA synthesis 10 to $30 \%$ (Silva et al., 2002a). That leptin in vivo completely blocked IGF-I stimulation of mammary epithelial cell proliferation in this study was unexpected. Our dose of $100 \mu \mathrm{g}$ of leptin/quarter per day increased leptin concentration of parenchymal tissue 25 -fold, so it is likely that the leptin infusions provided supraphysiological concentrations. The possibility that lower doses of leptin might have no effect or even a stimulatory 
effect on proliferation of mammary epithelial cells cannot be dismissed. In any case, our results are consistent with the idea that leptin may be partly responsible for the fact that the elevated IGF-I concentration in heifers fed high energy diets does not enhance the rate of mammogenesis.

Our results seem contradictory to the finding that leptin is necessary for physiologically normal mammary development in rodents (Hu et al., 2002) and that leptin stimulates mammary cell proliferation in human mammary cell lines (Dieudonne et al., 2002; Hu et al., 2002). Whether this is a species difference or simply due to dosage is not clear. Species differences do exist in expression of the leptin receptor, and these may explain the in vivo differences in ruminant and rodent responses. We are aware of no reports that rodent mammary epithelial cells express Ob-Rb, the long form of the leptin receptor, which has an intracellular domain. Activation of $\mathrm{Ob}-\mathrm{Rb}$, but not $\mathrm{Ob}-\mathrm{Ra}$, leads to activation of STAT (Bjorbaek et al., 1997). In addition, although co-incubation with bovine adipose tissue decreases proliferation of bovine mammary epithelial cells (McFadden and Cockrell, 1993), co-incubation with mouse fat pad stimulates proliferation of mouse mammary epithelial cells (Hovey et al., 1998).

Leptin has been shown to stimulate proliferation in some cancer cell lines and reduce proliferation in other cancer cell lines (Somasundar et al., 2003). In colonic epithelial cell lines, addition of leptin reduced proliferation of normal cells $\left(\mathrm{APC}^{+/+}\right)$but increased proliferation of a preneoplastic $\left(\mathrm{APC}^{\mathrm{Min} /+}\right)$ epithelial cell line, indicating that cancer cells may lose the ability to be inhibited by leptin (Fenton et al., 2005).

Our results were not caused by an inflammatory response of the mammary tissues to the leptin infusion. Our infusates had no detectable endotoxin, and there was no visible sign of mammary infection in any quarter during the course of the experiment or upon gross dissection. Although there was evidence of eosinophil infiltration into the parenchymal tissue of some quarters, the severity of infiltration was not related to treatment $(P>0.7)$ and was not correlated to BrdU-labeling of epithelial cells. This infiltration suggests hypersensitivity to the physical trauma of infusions or to the bovine serum albumin, which was included in the infusate at a concentration of $1 \mathrm{mg} / \mathrm{mL}, 100$ times that of leptin. However, we found similar eosinophil infiltration in the parenchymal tissue of noninfused, age-matched heifers, indicating this may be a normal phenomenon. Studies with rodents suggest that eosinophils play an essential role in mammary development, so perhaps the presence of eosinophils at a basal level should be expected (Gouon-Evans et al., 2002). In any case, the eosinophilic infiltration was not related to treatment. Thus, the number of local immune cells present in the tissues cannot explain the consistent effect of leptin on BrdUincorporation into epithelial cells in these heifers. Whether immune cells are somehow involved in the response is not clear.

Leptin receptor is a member of the gp130 family of membrane-bound receptors, a group that includes oncostatin M, IL-6, IL-11, LIF, and ciliary neurotrophic factor (Hutt and DeWille, 2002). These cytokines can signal through a common signaling subunit, glycoprotein 130 , to produce a variety of responses, including growth arrest of mammary epithelial cells (Hutt and DeWille, 2002). Insulin-like growth factor-I is a key regulator of cellular proliferation, survival, and differentiation in numerous cell types (Hadsell et al., 2002). Increasingly, studies are revealing that insulin and leptin signal transduction pathways show significant amounts of crosstalk across multiple tissue types (Carvalheira et al., 2005). Intracellular signaling for insulin and IGF are similar, and signaling interactions between IGF-I and leptin in the developing mammary gland seem likely.

In the current study, treatment had no effect on the number of cells committed to the cell cycle, as indicated by immunohistochemical labeling of the proliferating cell nuclear antigen Ki-67. The percentage of Ki-67 labeled cells ranged from 8.5 to $11.7 \%$, which agrees with previous results for mammary epithelial cells of prepubertal heifer (Capuco et al., 2004). Less than $0.25 \%$ of mammary epithelial cells across all treatments in our study were apoptotic as measured by caspase-3 labeling. This value is in line with the fraction of cells found to be apoptotic in the prepubertal mammary glands of heifers as measured by terminal deoxynucleotidyltransferase-mediated dUTP nick-end labeling (Musters et al., 2004). Although infusion of leptin increased the percentage of apoptotic cells in saline-treated quarters, the physiological significance of this effect is likely irrelevant, given the low percentage of cells that were apoptotic.

A specific effect of treatment on labeling with BrdU but not Ki-67 indicates altered progression of cells within the cell cycle rather than recruitment of cells from G0 into the cell cycle. Several studies have shown that IGF-I acts as a cell cycle progression factor, stimulating cyclin-dependent kinases and cyclins during the late G1 phase to advance cells into the S-phase and accelerate proliferation (Stull et al., 2002). Consistent with this, we have previously shown that intramammary infusions of IGF-I increase BrdU-labeling of epithelial cells (Silva et al., 2005).

The results presented in this study indicate that leptin may inhibit the progression of IGF-I-stimulated mammary epithelial cells into the S-phase of the cell 
cycle and leave them stranded in the G1-phase, thereby slowing proliferation. Although no studies have shown a direct inhibitory effect of leptin on cell cycle progression, it is possible that the interference with IGF-Istimulated proliferation could be mediated through a member of the suppressor of cytokine signaling (SOCS) family. Elevated SOCS-3 expression was associated with leptin inhibition of insulin signaling in rat adipocytes (Perez et al., 2004), and SOCS-1 has been established as a negative regulator of prolactin-induced proliferation in mice mammary gland (Lindeman et al., 2001).

In the current study, SOCS-3 mRNA was upregulated 3.4-fold in quarters infused with IGF-I plus leptin relative to IGF-I alone. Leptin had no effect on SOCS1 or SOCS-5 expression. This specificity has been observed by others. For example, peripheral leptin administration to $o b / o b$, but not $d b / d b$ mice, rapidly induced SOCS-3 mRNA in hypothalamus, but had no effect on CIS, SOCS-1, or SOCS-2 (Bjorbaek et al., 1998).

A leptin-induced increase in SOCS-3 protein level when the IGF-I receptor is activated, assuming protein changes mirror those of mRNA, might explain the inhibition of proliferation in mammary epithelial cells. A SOCS-mediated feedback mechanism may exist that works to decrease mammary epithelial cell sensitivity to the IGF-I mitogenic effect and thereby inhibits proliferation during periods of high energy feeding or increased adiposity in the ruminant. Decreased signaling through the IGF-I receptor would reduce progression to the S-phase of the cell cycle and slow proliferation. Future experiments measuring SOCS-3 protein levels and activation of critical components of the IGF-I and leptin signaling pathways, including STAT3, insulin receptor substrate 1 (IRS1), STAT5A and B, and JAK2 will be necessary to elucidate such a mechanism.

\section{CONCLUSIONS}

An increased leptin concentration in the physiologically normal bovine mammary gland reduces proliferation of mammary epithelial cells in vivo. The reduced proliferation is accompanied by an increase in SOCS-3 expression, suggesting a possible mechanism for leptin inhibition of IGF-I action. Our findings support the hypothesis that leptin may partly mediate the negative effect of high energy intake on mammogenesis in ruminants. Finally, these data provoke several questions, including whether leptin impairs mammogenesis at physiologically relevant concentrations, and, if so, what cell types and signaling mechanisms might be involved.

\section{ACKNOWLEDGMENTS}

We thank Ken Metz and the crew of the Beef Teaching and Research Center for their assistance in animal care.
This project was supported by National Research Initiative Competitive Grant no. 2003-35206-12873 from the USDA Cooperative State Research, Education, and Extension Service. Luis Felipe Prada e Silva received a PhD scholarship from CAPES-Brazil during the development of this project.

\section{REFERENCES}

Akers, R. M., T. B. McFadden, S. Purup, M. Vestergaard, K. Sejrsen, and A. V. Capuco. 2000. Local IGF-I axis in peripubertal ruminant mammary development. J. Mammary Gland Biol. Neoplasia 5:43-51.

Baratta, M., S. Grolli, and C. Tamanini. 2003. Effect of leptin in proliferating and differentiated HC11 mouse mammary cells. Regul. Pept. 113:101-107.

Baumann, H., K. K. Morella, D. W. White, M. Dembski, P. S. Bailon, H. Kim, C. F. Lai, and L. A. Tartaglia. 1996. The full-length leptin receptor has signaling capabilities of interleukin 6-type cytokine receptors. Proc. Natl. Acad. Sci. USA 93:8374-8378.

Bjorbaek, C., J. K. Elmquist, J. D. Frantz, S. E. Shoelson, and J. S. Flier. 1998. Identification of SOCS-3 as a potential mediator of central leptin resistance. Mol. Cell 1:619-625.

Bjorbaek, C., S. Uotani, B. da Silva, and J. S. Flier. 1997. Divergent signaling capacities of the long and short isoforms of the leptin receptor. J. Biol. Chem. 272:32686-32695.

Blache, D., R. L. Tellam, L. M. Chagas, M. A. Blackberry, P. E. Vercoe, and G. B. Martin. 2000. Level of nutrition affects leptin concentrations in plasma and cerebrospinal fluid in sheep. J. Endocrinol. 165:625-637.

Capuco, A. V., G. E. Dahl, D. L. Wood, U. Moallem, and R. E. Erdman. 2004. Effect of bovine somatotropin and rumen-undegradable protein on mammary growth of prepubertal dairy heifers and subsequent milk production. J. Dairy Sci. 87:3762-3769.

Capuco, A. V., D. L. Wood, R. Baldwin, K. Mcleod, and M. J. Paape. 2001. Mammary cell number, proliferation, and apoptosis during a bovine lactation: Relation to milk production and effect of bST. J. Dairy Sci. 84:2177-2187.

Carvalheira, J. B., M. A. Torsoni, M. Ueno, M. E. Amaral, E. P. Araujo, L. A. Velloso, J. A. Gontijo, and M. J. Saad. 2005. Crosstalk between the insulin and leptin signaling systems in rat hypothalamus. Obes. Res. 13:48-57.

Chelikani, P. K., D. R. Glimm, and J. J. Kennelly. 2003. Short communication: Tissue distribution of leptin and leptin receptor mRNA in the bovine. J. Dairy Sci. 86:2369-2372.

Chiu, J. J., M. K. Sgagias, and K. H. Cowan. 1996. Interleukin 6 acts as a paracrine growth factor in human mammary carcinoma cell lines. Clin. Cancer Res. 2:215-221.

Cowie, A. T., I. A. Forsyth, and I. C. Hart. 1980. Hormonal control of lactation. Monogr. Endocrinol. 15:I-XIV., 1-275.

Davis Rincker, L. E. 2005. Nutritional influences on body and mammary growth and regulation of leptin and IGF-I in prepubertal dairy heifers. PhD Diss. Michigan State University, East Lansing.

Delavaud, C., F. Bocquier, Y. Chilliard, D. H. Keisler, A. Gertler, and G. Kann. 2000. Plasma leptin determination in ruminants: Effect of nutritional status and body fatness on plasma leptin concentration assessed by a specific RIA in sheep. J. Endocrinol. 165:519-526.

Dieudonne, M. N., F. Machinal-Quelin, V. Serazin-Leroy, M. C. Leneveu, R. Pecquery, and Y. Giudicelli. 2002. Leptin mediates a proliferative response in human MCF7 breast cancer cells. Biochem. Biophys. Res. Commun. 293:622-628.

Fenton, J. I., N. G. Hord, J. A. Lavigne, S. N. Perkins, and S. D. Hursting. 2005. Leptin, insulin-like growth factor-1, and insulinlike growth factor-2 are mitogens in ApcMin/+ but not Apc+/+ colonic epithelial cell lines. Cancer Epidemiol. Biomarkers Prev. 14:1646-1652.

Gertler, A., J. Simmons, and D. H. Keisler. 1998. Large-scale preparation of biologically active recombinant ovine obese protein (leptin). FEBS Lett. 422:137-140. 
Gouon-Evans, V., E. Y. Lin, and J. W. Pollard. 2002. Requirement of macrophages and eosinophils and their cytokines/chemokines for mammary gland development. Breast Cancer Res. 4:155-164.

Hadsell, D. L., S. G. Bonnette, and A. V. Lee. 2002. Genetic manipulation of the IGF-I axis to regulate mammary gland development and function. J. Dairy Sci. 85:365-377.

Hovey, R. C., D. D. MacKenzie, and T. B. McFadden. 1998. The proliferation of mouse mammary epithelial cells in response to specific mitogens is modulated by the mammary fat pad in vitro. In Vitro Cell. Dev. Biol. Anim. 34:385-392.

Hu, X., S. C. Juneja, N. J. Maihle, and M. P. Cleary. 2002. LeptinA growth factor in normal and malignant breast cells and for normal mammary gland development. J. Natl. Cancer Inst. 94:1704-1711.

Hutt, J. A., and J. W. DeWille. 2002. Oncostatin M induces growth arrest of mammary epithelium via a CCAAT/enhancer-binding protein delta-dependent pathway. Mol. Cancer Ther. 1:601-610.

Kiupel, M., G. W. Stevenson, E. J. Galbreath, A. North, H. Hogenesch, and S. K. Mittal. 2005. Porcine Circovirus type 2 (PCV2) causes apoptosis in experimentally inoculated BALB/c mice. BMC Vet. Res. 1:7.

Kiupel, M., E. Teske, and D. Bostock. 1999. Prognostic factors for treated canine malignant lymphoma. Vet. Pathol. 36:292-300.

Klein, S., S. W. Coppack, V. Mohamed-Ali, and M. Landt. 1996. Adipose tissue leptin production and plasma leptin kinetics in humans. Diabetes 45:984-987.

Lindeman, G. J., S. Wittlin, H. Lada, M. J. Naylor, M. Santamaria, J. G. Zhang, R. Starr, D. J. Hilton, W. S. Alexander, C. J. Ormandy, and J. Visvader. 2001. SOCS1 deficiency results in accelerated mammary gland development and rescues lactation in prolactin receptor-deficient mice. Genes Dev. 15:1631-1636.

Livak, K. J., and T. D. Schmittgen. 2001. Analysis of relative gene expression data using real-time quantitative PCR and the 2(Delta Delta C(T)). Methods. 25:402-408.

McFadden, T. B., and D. C. Cockrell. 1993. Regulation of growth in cultured mammary epithelium from beef and dairy heifers. Proc. NZ Soc. Anim. Prod. 53:143-145.

Meyer, M. J., A. V. Capuco, D. A. Ross, L. M. Lintault, and M. E. Van Amburgh. 2006. Developmental and nutritional regulation of the prepubertal heifer mammary gland: I. Parenchyma and fat pad mass and composition. J. Dairy Sci. 89:4289-4297.

Musters, S., K. Coughlan, T. McFadden, R. Maple, T. Mulvey, and K. Plaut. 2004. Exogenous TGF-beta1 promotes stromal development in the heifer mammary gland. J. Dairy Sci. 87:896-904.

National Research Council. 2001. Nutrient Requirements of Dairy Cattle. 7th rev. ed. Natl. Acad. Press, Washington, DC.
Neter, J., M. H. Wasserman, C. Kutner, and J. Nachtsheim. 1996. Applied Linear Regression Models. 4th ed. Times Mirror Higher Education Group Inc., Los Angeles, CA.

Perez, C., C. Fernandez-Galaz, T. Fernandez-Agullo, C. Arribas, A. Andres, M. Ros, and J. M. Carrascosa. 2004. Leptin impairs insulin signaling in rat adipocytes. Diabetes 53:347-353.

Radcliff, R. P., M. J. VandeHaar, Y. Kobayashi, B. K. Sharma, H. A. Tucker, and M. C. Lucy. 2004. Effect of dietary energy and somatotropin on components of the somatotropic axis in Holstein heifers. J. Dairy Sci. 87:1229-1235.

SAS Institute Inc. 2000. Release 8.1. Cary, NC.

Sejrsen, K., and S. Purup. 1997. Influence of prepubertal feeding level on milk yield potential of dairy heifers: A review. J. Anim. Sci. 75:828-835.

Silva, L. F., J. S. Liesman, B. E. Etchebarne, M. S. Nielsen, and M. J. Vandehaar. 2005. Short communication: Intramammary infusion of IGF-I increases bromodeoxyuridine labeling in mammary epithelial cells of prepubertal heifers. J. Dairy Sci. 88:2771-2773.

Silva, L. F., M. J. VandeHaar, M. S. Weber Nielsen, and G. W. Smith 2002a. Evidence for a local effect of leptin in bovine mammary gland. J. Dairy Sci. 85:3277-3286.

Silva, L. F., M. J. VandeHaar, B. K. Whitlock, R. P. Radcliff, and H. A. Tucker. 2002b. Short communication: Relationship between body growth and mammary development in dairy heifers. J. Dairy Sci. 85:2600-2602.

Smith, J. L., and L. G. Sheffield. 2002. Production and regulation of leptin in bovine mammary epithelial cells. Domest. Anim. Endocrinol. 22:145-154.

Somasundar, P., A. K. Yu, L. Vona-Davis, and D. W. McFadden. 2003. Differential effects of leptin on cancer in vitro. J. Surg. Res. 113:50-55.

Stull, M. A., M. M. Richert, A. V. Loladze, and T. L. Wood. 2002. Requirement for IGF-I in epidermal growth factor-mediated cell cycle progression of mammary epithelial cells. Endocrinology 143:1872-1879.

Thorn, S. R., S. Purup, W. S. Cohick, M. Vestergaard, K. Sejrsen, and Y. R. Boisclair. 2006. Leptin does not act directly on mammary epithelial cells in prepubertal dairy heifers. J. Dairy Sci. 89:1467-1477.

Yamaji, D., A. Kamikawa, M. M. Soliman, T. Ito, M. M. Ahmed, K. Makondo, A. Watanabe, M. Saito, and K. Kimura. 2007. Leptin inhibits hepatocyte growth factor-induced ductal morphogenesis of bovine mammary epithelial cells. Jpn. J. Vet. Res. 54:183-189. 